Pobrane z czasopisma Annales I - Philosophy and Sociology http://philosophia.annales.umcs.pl Data: 26/04/2023 13:02:52

DOI: 10.17951/i.2016.41.2.139

A N N A LES

UNIVERSITATIS MARIAE CURIE-SKŁODOWSKA

LUBLIN - POLONIA

VOL. XLI, 2

SECTIO I

2016

PRZEMYSŁAW WROCHNA

Uniwersytet Marii Curie-Skłodowskiej w Lublinie

Intymność w stanie oblężenia

Intimacy in the State of Siege

\title{
WPROWADZENIE
}

W późno nowoczesnym (czy wręcz ponowoczesnym) świecie płynność zdaje się być jedyną stałą ${ }^{1}$. Permanentna zmiana dotyka takich aspektów egzystencji człowieka, jak jego kompetencje i kwalifikacje, wiedza o świecie, rytuały czy normy, które dotyczą jego życia. Nie jest to sytuacja idealna zarówno dla jednostki, jak i społeczeństwa, bowiem płynność jawi się jako niepewność. Wymaga ona przesunięcia na margines zastanych strategii i sposobów życia, dając w zamian niewiele pewnych i trwałych drogowskazów.

Socjologiczne rozważania dotyczące przemian zachodzących we współczesnym świecie prowadzą do tezy, iż znaleźliśmy się obecnie w miejscu, w którym zasadniczą rolę odgrywa proces indywidualizacji ${ }^{2}$. Według znanego naukowca, Norberta Eliasa, indywidualizacja (mniej lub bardziej dosadna) dotyka każdego

1 Z. Bauman, Liquid Modernity, Cambridge 2000; idem, Ponowoczesność jako źródło cierpień, Warszawa 2000.

2 U. Beck, Społeczeństwo ryzyka. W drodze do innej nowoczesności, przeł. S. Cieśla, Warszawa 2002; P. Berger, Rewolucja kapitalistyczna. Pięćdziesiąt tez o dobrobycie, równości $i$ wolności, przeł. Z. Simbierowicz, Warszawa 1995; Z. Bokszański, Indywidualizm a zmiana społeczna, Warszawa 2007; J. Dewey, Individualism Old and New, Amherst - New York 1999; A. Giddens, The Consequences of Modernity, Cambridge 1994; M. Jacyno, Kultura indywidualizmu, Warszawa 2007; R. Sennett, The Fall of Public Man. On the Social Psychology of Capitalism, New York 1996. 
Pobrane z czasopisma Annales I - Philosophy and Sociology http://philosophia.annales.umcs.pl Data: 26/04/2023 13:02:52

okresu rozwoju społecznego ${ }^{3}$. Natomiast zdaniem Mirosławy Marody zjawisko to w istocie „stanowi zwieńczenie procesu rozwoju ludzkości” 4 .

Abstrahując od danej kwestii, możemy niewątpliwie powiedzieć, iż rzeczywistość końca XX i początku XXI w. różni się znacząco od jej historycznie wcześniejszych form. Mam na myśli tutaj cały porządek gospodarczy, polityczny czy prawny, ale też istotne przemiany takich dziedzin, jak życie codzienne, sposoby spędzania czasu wolnego, sfera relacji międzyludzkich, w tym bliskich związków, które zajmują bardzo ważne miejsce w niemalże każdej ludzkiej biografii. W niniejszym opracowaniu pragnę zwrócić uwagę właśnie na ostatni z wymienionych aspektów, mianowicie na przemiany charakteru i form współczesnych relacji intymnych oraz związane z nimi napięcia, które zostaną ukazane w kontekście zachodzących obecnie procesów indywidualizacji.

\section{ZJAWISKO INDYWIDUALIZACJI}

Na wstępie należy zaznaczyć, iż zdefiniowanie procesu indywidualizacji jest zadaniem wielce problematycznym. Dzieje się tak dlatego, iż termin ten odnosi się do szerokiego spektrum różnorodnych dziedzin i aspektów życia ludzkiego. Proces ten koncentruje się wokół wytworów społecznych i kulturowych: norm i wartości oraz działań i modeli mentalnych konkretnych jednostek ${ }^{5}$. Podstawowy zakres problemowy, który jest rozważany w studiach nad tym zagadnieniem, stanowi opozycja wyznaczona na linii jednostka - zbiorowość.

Jak dowodzą badacze omawianego zjawiska, dzisiejsze przemiany odnoszą się bezpośrednio do jednostkowych losów ludzkich, oznaczając rozszerzenie gamy ich uprawnień i zawężeń zakresu ich obowiązków względem większych całości społecznych ${ }^{6}$. Myśl ta stanowi platformę do dalszych rozważań, ponieważ - zgodnie z opinią Zbigniewa Bokszańskiego - podniesienie roli jednostki oznacza wprost jej względną emancypację (,wolność od”) i autonomię (,wolność do”). Według tego polskiego naukowca zjawisko indywidualizacji, wyłaniając nowatorski model relacji indywiduum - społeczeństwo, w głównej mierze niesie ze sobą ideę pozytywnego wartościowania jednostki, wspierając jej poczucie własnego „JA” 7 , a także pozostawiając $\mathrm{w}$ jej zasięgu liczne narzędzia i sposoby samorealizacji.

\footnotetext{
3 N. Elias, Die Gesellschaft der Individuen, Frankfurt 1987.

4 M. Marody, Między neutralnościa a zaangażowaniem. O socjologii Norberta Eliasa, [w:] Spoleczeństwo jednostek, red. N. Elias, Warszawa 2008, s. 37.

5 Z. Bokszański, op. cit., s. 9.

6 J. Szacki, Indywidualizm i kolektywizm, [w:] Encyklopedia socjologii. Suplement, Warszawa 2005, s. 84-92.

Z. Bokszański, op. cit., s. 77-79.
} 
Pobrane z czasopisma Annales I - Philosophy and Sociology http://philosophia.annales.umcs.pl Data: 26/04/2023 13:02:52

Warto podkreślić, iż czynnik ,wyzwalający” jednostkę spod wpływu struktur i instytucji społecznych stanowi element szerszego procesu modernizacji (unowocześniania). Nowoczesne społeczeństwo, które wyklarowało się w ramach tego procesu, na przełomie XVIII i XIX w. znacząco zmieniło sytuację jednostek. Rozwój przemysłu (industrializacja) i kapitalizmu, masowe osiedlanie się w aglomeracjach miejskich wokół wielkich ośrodków przemysłowych (urbanizacja), znaczący rozwój komunikacji, większa mobilność społeczna oraz dezaktualizacja zasad dotychczas organizujących całe społeczności (np. zmiana statusu czy pozycji społecznej jednostek, która w zdecydowanie mniejszym stopniu była determinowana przez urodzenie i przynależność kategorialną) wyłaniają ,człowieka nowoczesnego”.

Aspekt ten podkreśla również Anthony Giddens, pisząc, iż „kwestia nowoczesności, jej rozwoju [...], zaistniała jako problem socjologiczny" ${ }^{8}$. Brytyjski socjolog dostrzega, iż ten ład społeczny różni się od wszelkich jego form na przestrzeni dziejów. Autor ma na myśli chociażby zmianę porządku instytucjonalnego czy przekształcenia w wymiarze tradycji i obyczajów. W rzeczywistości „tradycyjnej” miejsce jednostki w kontekście społecznym było określone przez szereg instytucji, jak np. rodzina, przynależność grupowa i klasowa, duże znaczenie odgrywał też Kościół. Te instytucje właśnie „ogarniały i definiowały całkowicie życie człowieka oraz jego relacje z innymi" 9 .

Jednak, jak wspomniałem we wstępie, zjawisko indywidualizacji jest także silnie korelowane z czasami nam współczesnymi. Zdaniem Marty Olcon-Kubickiej ludzie w dalszym ciągu podlegają emancypacji, w coraz większym stopniu ,uniezależniają się od wspólnot [...]. Przestają być identyfikowani jako przedstawiciele określonej grupy społecznej, stając się jednostkami i głównymi aktorami w nowym porządku społecznym" ${ }^{10}$. Polski socjolog, Piotr Sztompka, natomiast (podobnie jak Marody) przekonuje, jakoby dzisiejsza rzeczywistość była definiowana właśnie przez indywidualizację. Dzieje się tak za sprawą jednostki:

[...] wolnej od narzuconych więzi grupowych i uzależnień, obdarzonej godnością i niezbywalnymi prawami nie tylko jako obywatel, członek społeczeństwa, ale jako osoba ludzka, decydująca samodzielnie o kształcie swojej biografii, mająca do dyspozycji wiele wzorów życia czy kariery, a także ponosząca wyłączną odpowiedzialność za swoje sukcesy czy porażki ${ }^{11}$.

Jak podkreślają owi naukowcy, w dzisiejszym układzie jednostka sama określa poziom swojego uczestnictwa i zaangażowania w życie obywatelskie, religijne, grupowe, rodzinne czy towarzyskie. Warto dodać, iż obecne instytucje mogą - ale

\footnotetext{
8 A. Giddens, Nowoczesność i tożsamość, przeł. A. Szulżycka, Warszawa 2012, s. 11.

9 M. Olcoń-Kubicka, Indywidualizacja a nowe formy wspólnotowości, Warszawa 2009, s. 23.

10 Ibidem, s. 7.

11 P. Sztompka, Socjologia. Analiza społeczeństwa, Kraków 2012, s. 579.
} 
Pobrane z czasopisma Annales I - Philosophy and Sociology http://philosophia.annales.umcs.pl Data: 26/04/2023 13:02:52

nie muszą - pełnić rolę socjalizującą czy integrującą ludzi. Zgodnie z powiedzeniem „natura nie znosi próżni” w środowisku społecznym pusta przestrzeń zostaje wypełniona. W miejsce starych, zdezaktualizowanych struktur momentalnie pojawiają się nowe formy wspólnotowości, które - jak dowodzi Olcoń-Kubicka - są mniej sformalizowane, a zatem mniej widoczne, sztywne i determinujące losy jednostek $^{12}$. Te nowe rodzaje wspólnot czy mechanizmów integracji są tworami płynnymi i dynamicznymi (np. grupy i stowarzyszenia sieciowe - wirtualne), mają charakter inkluzyjny, otwarty oraz zorientowany ,przede wszystkim na jednostkę, jej cele i potrzeby” ${ }^{13}$, szanując jej autonomię. Dlatego „zindywidualizowana nowoczesność" nie oznacza świata bez struktur grupowych. Indywidualizacja może się tym samym prezentować jako swoista forma uspołecznienia, stanowiąc o nowej jakości integrującej społeczeństwo i wpływającej na tworzone w jej obrębie wspólnoty oraz zawierane relacje międzyludzkie.

Wspomniany powyżej nowy mechanizm integrujący nie odgrywa jednak tak determinującej roli dla biografii człowieka, jak zdezintegrowane tradycyjne struktury i instytucje. Według Ulricha Becka niezależnie od poziomu zaangażowania w jakąkolwiek formę wspólnotowości dzisiejsza rzeczywistość wymusza u ludzi konieczność aktywnego, jednostkowego procedowania nad każdym aspektem swojego życia. Jak zaznacza słynny niemiecki socjolog, „biografia człowieka, wyzwolona od zastanych stosunków, otwarta i uzależniona od własnych decyzji, zostaje przekazana jednostce jako zadanie, które ma ona realizować w swych działaniach" ${ }^{14}$. Współczesny człowiek tym samym musi ponosić ciężar decyzji dotyczących własnego wykształcenia, kariery, wyboru partnera czy liczby posiadanych dzieci, ale też takich kwestii, jak ułożenie właściwej diety, sposób spędzania czasu wolnego oraz zakup określonej marki samochodu.

Problem ten prowadzi nas do (wydaje się) powszechnie znanego i stosowanego obecnie pojęcia stylu życia. Według Giddensa „style życia są zrutynizowanymi praktykami, które odpowiadają nawykom żywieniowym, sposobom ubierania się, zachowania i zwyczajom spotykania się w ulubionych miejscach" ${ }^{15}$. Praktyki te stanowią pole dla doświadczania siebie, są ,jedną z form autoekspresji i [...] »wyrazem « tego, kim jest jednostka" ${ }^{16}$. Stylizacja życia daje ludziom możliwość pełnego definiowania własnego „sposobu bycia” w świecie. Oznacza to, iż ,jednostka w coraz większym stopniu kieruje się ku sobie, ciągle analizując swoją

\footnotetext{
12 M. Olcoń-Kubicka, op. cit., s. 84.

Ibidem, s. 85.

U. Beck, op. cit., s. 202.

A. Giddens, Nowoczesność..., s. 115

M. Jacyno, op. cit., s. 58.
} 
Pobrane z czasopisma Annales I - Philosophy and Sociology http://philosophia.annales.umcs.pl Data: 26/04/2023 13:02:52

kondycję duchową, stany emocjonalne oraz aktualną sytuację życiową" ${ }^{17}$. Dlatego może to prowadzić do deliberowania nad stanami i kwestionowania tych, które „kiedyś traktowano jako oczywiste [...]. Taki obszar stanowią między innymi relacje w związku małżeńskim i wszelkie decyzje z nim związane" 18 .

Wspomniałem już, że proces indywidualizacji, przekształcając ,,położenie jednostki w społeczeństwie" ${ }^{19}$, przyczynia się również do pewnej jakościowej zmiany w sferze relacji międzyludzkich. Oczywiste wydaje się być to, że transformacja zasad, mechanizmów i sposobów spostrzegania własnego „bycia” w świecie redefiniuje także reguły dotyczące kwestii „współbycia”. Zdaniem niemieckich badaczy, Ulricha Becka i Elisabeth Beck-Gersheim, zbytnia internalizacja założeń indywidualizmu i zaintrygowanie aspektem własnego ,ja” może się jawić jako przeszkoda w pełniejszym zainteresowaniu kwestiami „my” ${ }^{20}$. Według Giddensa natomiast mamy obecnie do czynienia $\mathrm{z}$ istotną zmianą $\mathrm{w}$ charakterze rodzinnych, małżeńskich oraz bliskich i osobistych więzi. Badacz, akcentując autonomiczność i wielość możliwości, zgodnie z którymi jednostka może dokonywać licznych wyborów, dostrzega ich wpływ na wymiar relacji międzyludzkich, rzutując przede wszystkim w samo sedno przemian sfery intymności.

Intymność oznacza tutaj coś, co ma charakter ,ściśle osobisty [...]; bliski, zażyły" ${ }^{21}$. Zatem będzie się ona odwoływać do wielu form interakcji międzyludzkich, takich jak relacje rodzinne, przyjacielskie, romantyczne czy erotyczne. Zgodnie z myślą Giddensa „Związki intymne i przyjazne w systemach nowoczesnych charakteryzują się dowolnością wyboru spośród wielu możliwych partnerów" 22 . Aspekt ten sprawia, że współcześnie jednostki stoją wobec pewnej „konieczności wyboru nieskończonej liczby możliwości tworzenia, poprawy, naprawy i rozwiązywania swoich związków z innymi" ${ }^{23}$. Przy tym tradycyjne reguły i mechanizmy („stabilizacyjne”) oraz wyobrażenia dotyczące związków przestają obowiązywać. Czy wynik procesów indywidualizacji, przesuwając w zasadniczy sposób akcent z „my” na ,ja”, przyczynia się do „kryzysu” dzisiejszych bliskich relacji intymnych?

17 M. Olcoń-Kubicka, op. cit., s. 30.

18 Ibidem.

19 Ibidem, s. 14.

20 U. Beck, E. Beck-Gersheim, The Normal Chaos of Love, Cambridge 1995, s. 54.

21 W. Kopaliński, Intymność, [w:] Słownik wyrazów obcych i zwrotów obcojęzycznych, Warszawa 1998, s. 235.

22 Ibidem, s. 123.

23 A. Giddens, Socjologia, przeł. P. Tomanek, A. Szulżycka, O. Siara, Warszawa 2012, s. 198. 
Pobrane z czasopisma Annales I - Philosophy and Sociology http://philosophia.annales.umcs.pl Data: 26/04/2023 13:02:52

\section{BLISKIE RELACE W DOBIE PRZEMIAN}

Zanim przejdę do próby odpowiedzi na postawione wyżej pytanie, warto podkreślić, że dyskusje dotyczące „kondycji” związków międzyludzkich, rodziny czy samej intymności jawią się jako problem charakterystyczny dla czasów nam współczesnych (podobnie jak omawiane powyżej kwestie indywidualizacyjne). Jak podkreślają liczni badacze tego zjawiska ${ }^{24}$, dylematy takie, jak „,rozkład” rodziny czy „wątpliwa trwałość” związków międzyludzkich, stanowią element rozważań naukowych już od kilku stuleci. Modernizacja bowiem, oprócz masowych procesów, postępującej emancypacji (w tym w aspekcie ról płciowych) i przekształceń wielkich struktur społecznych, dotyka także sfery mikrospołecznej.

Przednowoczesny (tradycyjny) model rodzinno-małżeński czytelnie nakreślał role małżonków oraz wynikające z nich prawa i powinności. Typ ten regulował takie dziedziny, jak: życie codzienne, funkcjonowanie gospodarstwa domowego czy aktywność seksualna. Obowiązkiem kobiety było przede wszystkim troszczenie się o domostwo i zaspokajanie pragnień seksualnych i rozrodczych ${ }^{25}$. Mężczyzna był natomiast zobligowany do konsekwentnego zapewniania bytu (materialnego) rodzinie, z tytułu czego zyskiwał pozycję ,głowy rodziny”. Samo małżeństwo zaś stanowiło główną formę egzystencji jednostki w społeczeństwie. Nakreślało bowiem jej status społeczny, role, funkcje i przydatność dla samego społeczeństwa. Trafnie konkluduje to Krystyna Slany, pisząc, iż „generalnie istniała niemożność życia poza małżeństwem" ${ }^{26}$. W ten sposób życie jednostki uzyskiwało charakter kompletnej „narracji” i było pozbawione tego, co obecnie może się jawić jako warunek sine qua non funkcjonowania w rzeczywistości społecznej, tj. indywidualności.

Warto podkreślić, iż tradycyjne małżeństwo często było ujmowane jako wspólnota czysto ekonomiczna. Anthony Giddens wspomina, że „w Europie przednowoczesnej większość małżeństw była zawierana nie z uwagi na wzajemną fascynację [...], ale ze względów ekonomicznych" ${ }^{27}$. W tamtym czasie to właśnie motywacje materialne decydowały o zawarciu małżeństwa, a wybór partnera często był

24 G. Burkhart, Familiensoziologie, Konstanz 2008; K. Craft, Równości i nierówności w II Rzeczypospolitej. Prawo matżeńskie $w$ dyskursie publicznym na przełomie lat dwudziestych i trzydziestych, [w:] Kobieta i matżeństwo. Społeczno-kulturowe aspekty seksualności. Wiek XIX $i$ XX, red. A. Żarnowska, A. Szwarc, Warszawa 2004, s. 311-327; J. Żarnowski, Rodzina w czasach cywilizacyjnego przyśpieszenia: Europa i Polska 1918-1989, [w:] Rodzina, prywatność, intymność, red. D. Kawała, A. Walaszek, A. Żarnowska, Warszawa 2005, s. 37-58.

25 C.M. Renzetti, D.J. Curran, Kobiety, mężczyźni i społeczeństwo, przeł. A. Gromkowska-Melosik, Warszawa 2005, s. 259.

26 K. Slany, Alternatywne formy życia matżeńsko-rodzinnego w ponowoczesnym świecie, Kraków 2002, s. 55.

27 A. Giddens, Przemiany intymności, przeł. A. Szulżycka, Warszawa 2015, s. 53. 
Pobrane z czasopisma Annales I - Philosophy and Sociology http://philosophia.annales.umcs.pl Data: 26/04/2023 13:02:52

zależny od decyzji rodziców. Powszechnym poglądem była też niechęć do tzw. małżeństw „nierównych” ${ }^{28}$ (np. szlachcica z chłopką), które były postrzegane jako związki niestosowne, określane mianem mezaliansu. Małżeństwo stanowiło bowiem o reprodukcji reguł społecznych, które ogarniały życie jednostek. Zdaniem wybitnego niemieckiego socjologa, Georga Simmla, kiedy mówimy o instytucji małżeństwa (przednowoczesnego):

[...] nie sposób przeoczyć ogromnej roli, jaką [...] odgrywają w nim osoby trzecie, często nawet nie krewni - w zalotach, przy omawianiu posagu, w obyczaju weselnym - łącznie z udzielającym sakramentu kapłanem. To nieosobiste spoiwo małżeństwa znamionuje wyjątkowość tej struktury społecznej: zarówno treść, jak i forma owego najbardziej osobistego związku jest dziełem obiektywnych instytucji historyczno-społecznych. Ta interwencja tradycji w istotę stosunku małżeńskiego, która przeciwstawia go swobodnej formie, np. związku przyjaźni i dopuszcza totalną akceptację lub odrzucenie, lecz nie korekty, sprzyja powstaniu poczucia obiektywnego, ponadindywidualnego charakteru małżeństwa. Mimo że każdy z partnerów związany jest tylko z jedną osobą, to przynajmniej częściowo czuje się złączony poniekąd z kolektywem, jako prosty element struktury ponadindywidualnej - co do swej istoty i co do swych norm od niego niezależnej ${ }^{29}$.

Nowoczesność jednak redefiniuje ten porządek. Ta patriarchalna, trwała i multifunkcyjna instytucja społeczna zaczęła zmierzać ku dezaktualizacji ${ }^{30}$. W konsekwencji została zastąpiona przez relatywnie demokratyczną i mniej „skostniałą” relację „opartą na miłości, z ograniczonymi funkcjami, z których te osobowe stają się najważniejsze" ${ }^{31}$. Zmieniają się przede wszystkim ekonomiczne podstawy funkcjonowania rodziny, ponieważ działalność produkcyjna w znacznej części zostaje odcięta od gospodarstw domowych. Co prawda, w dalszym ciągu trudnią się one pracą na roli, lecz część domowników poszukuje innych form zatrudnienia (poza rolnictwem), napływając coraz liczniej ze wsi do miast. W związku z tym dochodzi do demontażu pozycji ojca jako niepodważalnego autorytetu i pana domu - przestaje być on jedynym żywicielem rodziny. Ponadto migracje do przemysłowych ośrodków miejskich przyczyniły się do wyklarowania wielu różnych wartości, motywacji i aspiracji oraz sposobów na życie. Istotny jest także fakt, iż znaczenia zaczynają nabierać „upośledzone” dotąd

28 K. Tymicki, Starokawalerstwo i staropanieństwo. Analiza zjawiska, „Studia Socjologiczne" 2001, nr 163.

29 G. Simmel, Socjologia, przeł. M. Łukasiewicz, Warszawa 2005, s. 100.

30 Por. F. Adamski, Rodzina, wymiar społeczno-kulturowy, Kraków 2002; L. Kocik, Wzory matzeństwa i rodziny od tradycyjnej jednorodności do wspótczesnych skrajności, Kraków 2002; J. Styk, Ewolucja chtopskiego systemu wartości, Lublin 1988; Z. Tyszka, Rodzina współczesna-jej geneza i kierunki przemian, [w:] Wspótczesne rodziny polskie - ich stan i kierunek przemian, red. Z. Tyszka, Poznań 2001.

31 K. Slany, op. cit., s. 52. 
Pobrane z czasopisma Annales I - Philosophy and Sociology http://philosophia.annales.umcs.pl Data: 26/04/2023 13:02:52

kategorie społeczne - w szczególności kobiet, które wkraczając na rynek pracy, reinterpretują tradycyjnie ujmowane role małżeńskie.

Członkowie rodzinny pełnią odtąd również inne niż tradycyjne role (rodzinne), jak np. pracownik, uczeń, obywatel, członek partii politycznej czy stowarzyszenia itp. Rodzina (jej członkowie), niejako z konieczności funkcjonując w wielu różnych, zewnętrznych wobec siebie, kontekstach (społecznym, ekonomicznym, prawnym i kulturowym), zostaje wtłoczona w krąg licznych, przecinających się wzajemnie interakcji. Przykładowo kobieta nie jest tylko żoną, matką, opiekunką ogniska domowego. Zarazem może figurować jako pracownik, przyjaciel, członek grupy, studentka uniwersytetu, stykając się z różnymi kontekstami, odmiennymi doświadczeniami oraz rodzajami wiedzy i poglądów ${ }^{32}$. W wyniku tych przynależności, jak pisze Filip Schmidt, „rodzi się [...] jednostka - obdarzona indywidualnymi prawami, szansami i pragnieniami, które usiłuje w sobie odczytać" ${ }^{33}$.

Przemiany te zyskują na zasięgu i dynamice. W drugiej połowie XX w. masowe zmiany obyczajowe (chociażby „rewolucja seksualna”) podwyższyły znacząco status kobiety w społeczeństwie i małżeństwie. Kobiety we współczesnym świecie stają się również beneficjentkami związku. Nabywają świadomość siebie i swojej pozycji w związku oraz prawo do czerpania satysfakcji na równi ze swoim partnerem. Potrzeby i pragnienia kobiet okazują się być równie istotne, natomiast oczekiwania względem poszanowania ich aspiracji jawią się jako jak najbardziej zasadne. Związki nie są zawierane ze względu na czynniki ekonomiczne, a pary rzadziej ulegają sugestiom ze strony rodziców odnośnie do wyboru partnera. Ze względu na karierę i edukację, małżeństwa - kiedy już do nich dochodzi - zawierane są znacznie później niż w przypadku poprzednich dziesięcioleci, a decyzje dotyczące prokreacji odwlekane są w czasie. Zwiększa się też ogólna liczba zawieranych związków w trakcie całego życia, motywowana pragnieniem odnalezienia „właściwego" partnera. W tym sensie o podstawie dobrego związku zaczyna świadczyć kwestia intymności, wzajemności, akceptacji i troski o siebie. Cechy te jawią się jako źródło satysfakcji wynikającej z obcowania z drugą osobą.

\section{(NIE)CZYSTA RELACJA INTYMNA?}

Jak piszą Ulrich Beck i Elisabeth Beck-Gernshein, mamy obecnie do czynienia z tzw. kolejną „małą rewolucją francuską”. Zgodnie z nią dotychczasowy

32 To samo dotyczy także ról, jakie pełni mężczyzna.

33 F. Schmidt, Para, mieszkanie, matżeństwo. Dynamika zwiazków matżeńskich intymnych na tle przemian historycznych $i$ wspótczesnych dyskusji o procesach indywidualizacji, Warszawa - Toruń 2015, s. 85. 
Pobrane z czasopisma Annales I - Philosophy and Sociology http://philosophia.annales.umcs.pl Data: 26/04/2023 13:02:52

porządek w zakresie intymności jest atakowany przez nowe, ale w gruncie rzeczy stare i „niespełnione obietnice wolności i niezależności” ${ }^{34}$. Niemieccy badacze dostrzegają w tendencjach dotyczących współczesnej intymności znaczny potencjał emancypacyjny i indywidualizujący.

Na potencjał ten (być może nawet bardziej od pary niemieckich socjologów) zwraca uwagę także Giddens. Jego zdaniem współczesne bliskie relacje zmierzają do modelu tzw. czystej relacji ${ }^{35}$. W przeciwieństwie do więzi zawieranych w społeczeństwach tradycyjnych (opartych w znacznym stopniu na czynnikach zewnętrznych) czysta relacja odnosi się wprost do swobodnego uczestnictwa jej członków. Dzisiejsza relacja:

[...] staje się w coraz większej mierze związkiem tworzonym i podtrzymywanym o tyle, o ile bliski kontakt z drugą osobą jest źródłem satysfakcji emocjonalnej [...]. Inne jego aspekty, nawet pozornie tak fundamentalne, jak posiadanie dzieci, nie tylko nie cementują związku, ale mogą przyczyniać się do jego postępującego rozkładu ${ }^{36}$.

Giddensowska relacja „ma wartość tego, co sama oferuje partnerom” ${ }^{37}$, a partycypacja w niej zależy od poziomu satysfakcji wynikającego z tego związku. To właśnie satysfakcja (zaspokajanie potrzeb i oczekiwań partnera) ma w danym układzie fundamentalną wartość - inne czynniki są zdecydowanie drugorzędne. Giddens podsumowuje postawioną tezę, pisząc, iż ,jednostki wchodzą w związek dla niego samego, czyli dla tego, co każda z nich może wynieść z trwałej więzi z drugą osobą" ${ }^{38}$. Czynniki scalające parę w poprzednich pokoleniach, zgodnie z myślą autora, zmieniły się obecnie w sposób znaczący. Obecny „czysty związek” jest w pewnym sensie „transakcją”, w której obie strony ,inwestują” pewne pokłady „siebie” i w nieustannym rachunku zysków i strat oczekują od drugiej strony wywiązania się z zawartej „umowy”.

W tym momencie w sposób oczywisty pojawia się pytanie o miejsce uczucia, jakim jest miłość w tym układzie. Brytyjski socjolog odpowiada jednoznacznie, iż czysta relacja jest miłością, lecz współcześnie różniącą się od jej rodzajów na przestrzeni wieków. Jednym z rodzajów miłości jest jego zdaniem tzw. miłość namiętna (amour passion), która jest „wyrazem integralnej więzi między miłością a seksem" ${ }^{39}$. Jest to koncepcja dosyć uniwersalna, występująca w społeczeństwach od niepamiętnych czasów. Dane uczucie nie musi zamykać się w obrębie dwóch

\footnotetext{
U. Beck, E. Beck-Gersheim, op. cit., s. 7.

A. Giddens, Nowoczesność..., s. 123.

Ibidem, s. 126.

Ibidem, s. 127.

Idem, Przemiany..., s. 79.

Ibidem, s. 52.
} 
Pobrane z czasopisma Annales I - Philosophy and Sociology http://philosophia.annales.umcs.pl Data: 26/04/2023 13:02:52

partnerów i często przybiera formę seksu pozamałżeńskiego. Drugim rodzajem jest „miłość romantyczna”, która opiera się na „projekcyjnej identyfikacji amour passion jako sile przyciągającej do siebie przyszłych partnerów i wiążącej ich ze sobą" ${ }^{40}$. Jest to bardziej specyficzne uczucie mówiące o możliwości trwałej więzi między dwojgiem ludzi. W związku tym druga osoba jest traktowana jako wyjątkowa - jest idealizowana w oczach partnera. Każdy z tych modeli oczywiście może występować w dowolnym okresie historycznym, ale - jak przekonuje Giddens - pierwszy z nich był charakterystyczny dla czasów przednowoczesnych, zaś drugi rozkwitł wraz z nowoczesnością.

Zdaniem Giddensa obecnie ,ideały miłości romantycznej kruszą się pod naciskiem seksualnej emancypacji i autonomii" ${ }^{41}$. Dlatego trzecim modelem więzi intymnej (realizowanym współcześnie) jest tzw. miłość współbieżna. Jest ona „miłością czynną i warunkową i jako taka kłóci się z »tylko« i »na zawsze« kompleksu miłości romantycznej” ${ }^{42}$. Nie chodzi tutaj o odnalezienie „kogoś szczególnego”, lecz o zaprojektowanie „szczególnej relacji”. Intymność w tym sensie może być rozumiana w kategoriach indywidualistycznych jako forma „negocjowanych interakcji" ${ }^{43}$. Związek oparty na takim rodzaju miłości jest zatem w pewnym sensie „otwarciem się" na partnera, przepracowaniem wspólnych słabości w celu osiągnięcia obopólnej satysfakcji.

Miłość współbieżna, oparta na idei wolności i otwartości partnerów, koncentruje się wokół kwestii zaangażowania i wzajemnego zaspokajania potrzeb oraz egalitarności w związku. Model miłości romantycznej zdecydowanie podkreślał „nierówność” płci i wynikającą z niej odmienność pełnionych ról w bliskiej relacji (które wynikały z obyczaju: kobieta powinna być adorowana, a mężczyzna winien o nią zabiegać; niektóre obowiązki domowe były zarezerwowane głównie dla kobiety, mężczyźnie nie wypadało ich wykonywać). Miłość współbieżna natomiast jako fundament czystej relacji neguje ten podział, a trwałość związku zależy od stopnia zaangażowania i zadowolenia uczestników tej relacji. Zadowolenie i satysfakcja mają tutaj kluczowe znaczenie, ponieważ nie ma przymusu trwania w niesatysfakcjonującym związku. Gdy uczucie (w tym satysfakcja) wygasa, ważność traci również sama relacja.

Intymność zatem jest polem stosunków międzyludzkich materializującym się w wyrażaniu wzajemnej bliskości. W parze z nią idzie oddanie. Jak podkreśla

$40 \quad$ Ibidem, s. 79.

41 Ibidem.

42 Ibidem, s. 79-80.

43 M. Grochalska, Kobiety w zwiąkach jako ofiary dyskursu ,szczęśliwej rodziny”, [w:] Zagadnienia malzeństwa i rodziny w perspektywie feministyczno-genderowej, red. K. Slany, Kraków 2013, s. 146. 
Pobrane z czasopisma Annales I - Philosophy and Sociology http://philosophia.annales.umcs.pl Data: 26/04/2023 13:02:52

Giddens, żaden układ czy więź „nie może istnieć bez wzajemności” ${ }^{44}$, a zdecydowanie nie osobisty związek dwóch partnerów. W szczególności, kiedy na sile tracą wszelkie uwarunkowania i determinacje zewnętrzne, oddanie jest klamrą spajającą cały związek oraz źródłem zadowolenia i satysfakcji. Dlatego współczesna relacja intymna jest konstruktem wielce „zdemokratyzowanym”. W tym sensie pojęcie to odnosi się zarówno do stopnia emancypacji samej relacji, jak i sposobu określania stron związku. Są one równorzędnymi i wolno działającymi podmiotami, a układ, który tworzą, wspólnie wyraża się przez partnerstwo i poszanowanie każdej ze stron. Zdaniem brytyjskiego socjologa obecne związki pozwalają jednostkom na osiągnięcie wolności od społecznych konwenansów (np. konieczności zawarcia małżeństwa), a współbycie jawi się teraz jako przedmiot dyskusji i uzgodnień ${ }^{45}$.

Koncepcja autora przez lata doczekała się wielu omówień i opracowań ${ }^{46}$ oraz uwag krytycznych ${ }^{47}$. Czystość Giddensowskiej relacji polega na tym, że jej kształt i specyfika zależą w głównej mierze od jednostek w niej uczestniczących. Relacje te nie są ,zabrudzone” w żaden sposób przez regulacje zastane i nakazy zewnętrzne. Jest to argument niewątpliwie pozostający w duchu omawianych w tej pracy założeń indywidualizacji (kiedy to biografia jednostki jest w głównej mierze uzależniona od jej własnych decyzji, podobnie jak doświadczenia dotyczące więzi międzyludzkich). Gdy jednak przyjmiemy założenie, iż zjawisko indywidualizacji jest pewną formą uspołecznienia - pierwotną wobec działań jednostek - to można dostrzec, że wszelkie układy międzyludzkie niejako „stwarzają” jednostkę jako: męża, żonę, ojca, matkę, partnera/partnerkę, syna, córkę czy członka wielu różnych grup. Dodatkowo wspomniana uprzednio konieczność pełnienia przez jednostkę wielu ról równocześnie powoduje u niej czerpanie z rozmaitych schematów poznawczych i wartości ${ }^{48}$, co może prowadzić do poczucia dysonansu.

44 A. Giddens, Nowoczesność..., s. 130.

45 Idem, Przemiany..., s. 221-222.

46 G. Ronek, Koncepcja demokratycznej rodziny Anthony'ego Giddensa, [w:] Miłość, wierność, uczciwość na rozstajach wspótczesności. Kształty rodziny współczesnej, red. W. Muszyński, E. Sikorska, Toruń 2008; E. A. Sekuła, Giddens o miłości i nie tylko. Recenzja książki „Przemiany intymności” A. Giddensa, „Kultura Popularna” 2006, nr 4.

47 Zob. L. Jamieson, Intimacy Transformed? A Critical look at "Pure Relationship", "Sociology" 1999, Vol. 33, DOI: https://doi.org/10.1017/S0038038599000310, s. 477-499; M. Homeles, The Preciarnousness of Choice in the New Sentimental Order: A Response to Bawin-Legros, "Current Sociology" 2004, Vol. 52, s. 251-257.

48 W konsekwencji czego owe wartości, normy i schematy poznawcze oddziałują niejako na postawy jednostek, ich działania i sposób patrzenia na świat. Rzeczywistość społeczna jest tutaj filtrem, przez który przechodzą wszelkie decyzje - także te dotyczące relacji intymnej (jej formy, modelu, oczekiwań względem partnera czy samego związku). 
Pobrane z czasopisma Annales I - Philosophy and Sociology http://philosophia.annales.umcs.pl Data: 26/04/2023 13:02:52

Według Filipa Schmidta to właśnie z tego dysonansu rodzi się refleksyjność jednostki. Wynika ona nie tyle z kwestii uwolnienia się od zewnętrznych ograniczeń, ile z rozziewu między różnymi sposobami funkcjonowania w świecie, sprzecznymi wizjami i oczekiwaniami towarzyszącymi pełnionym rolom oraz zapośredniczeniu różnorodnych wizji, dotyczących chociażby związków międzyludzkich ${ }^{49}$. Refleksyjność i autonomiczność jest w głównej mierze pragnieniem zredukowania tego dysonansu, wyboru najbardziej pasujących w danym momencie rozwiązań. Zdaniem autora tworzone relacje intymne nie są niezależnymi układami w szerszym kontekście społecznym, a raczej efektem synergii sieci wielu wizji i doświadczeń związkowych. Dostrzega to także Jan Kmita w swojej społeczno-regulacyjnej koncepcji kultury ${ }^{50}$, zgodnie z którą niektóre intencje i podejmowane przez jednostki działania nie są do końca skorelowane z ich refleksyjnością. Część z nich stanowi nieuświadomiony efekt wpływu kultury na jednostkę. Skąd bowiem jednostki mają przekonanie o tym, jak wygląda satysfakcjonujący związek? Jakie oczekiwania i pragnienia muszą być bezwzględnie spełnione do utrzymania związku, a które stanowią obiekt negocjacji i kompromisów?

\section{ZWIĄZKI INTYMNE W STANIE OBLĘŻENIA}

Pozostawiając te pytania na boku, warto podkreślić, iż pole bliskich stosunków międzyludzkich może ich uczestnikom jawić się jako źródło licznych napięć i zagrożeń. Zdaniem Moniki Torczyńskiej-Jareckiej zindywidualizowane „społeczeństwo traci swoją spoistość i trwałość" ${ }^{1}$. Zawierane obecnie więzi intymne są kruche i efemeryczne. Natomiast zakres możliwości i relatywna dowolność w kreowaniu zarówno swojego życia, jak i relacji z innymi może nieść dla jednostek wiele negatywnych konsekwencji.

Owa kruchość związków niesie ze sobą poczucie niepewności i utraty bezpieczeństwa ontologicznego. Cechą relacji intymnej coraz częściej wydaje się być fakt, iż „każdy z partnerów, właściwie w dowolnym momencie, może ją zerwać. Aby relacja mogła trwać, konieczne jest zaangażowanie, ale każdy, kto angażuje się bez pamięci, ryzykuje, że w przyszłości, jeśli związek się rozpadnie, może zostać bardzo zraniony" ${ }^{52}$. Zatem uczestnik takiej relacji nie może być w pełni przekonany

49 F. Schmidt, Teorie kuchenne. Dialektyka przyzwyczajeń i refleksyjności w koncepcji Jeana Claude'a Kaufmanna, „Kultura i Społeczeństwo” 2010, nr 1.

50 J. Kmita, O kulturze symbolicznej, Warszawa 1982.

51 M. Torczyńska-Jarecka, Samotność z wyboru jako alternatywny styl życia, [w:] Kulturowe wyzwania XXI wieku. Szkice z socjologii, antropologii i psychologii społecznej, red. U. Kusio, Lublin 2005, s. 95.

52 A. Giddens, Przemiany..., s. 164. 
Pobrane z czasopisma Annales I - Philosophy and Sociology http://philosophia.annales.umcs.pl Data: 26/04/2023 13:02:52

co do trwałości związku, bowiem każda ze stron ma świadomość, że trwa on aż do „odwołania”. Zdaniem Dorothy Popenoe może się to wiązać z tzw. paradygmatem elastyczności ${ }^{53}$. Współcześnie elastyczność stanowi wartość nadrzędną w wielu dziedzinach rzeczywistości (chociażby na rynku pracy), jednak zgodnie z takim rozumowaniem, gdy rozważamy kwestię relacji międzyludzkich, koniec związku nie musi oznaczać sytuacji negatywnej. Dzieje się tak, ponieważ zmiana może okazać się szansą na odnalezienie właściwej - satysfakcjonującej - relacji ${ }^{54}$.

Elastyczność, płynność czy otwartość widać w przypadku przemian form zawieranych związków. Instytucja małżeństwa, która przez lata była obowiązującym wzorcem „bycia razem”, aktualnie nie jest postrzegana jako jedyna droga do „osiągnięcia szczęścia”. Przykładem mogą być tutaj wszelkiego rodzaju więzi alternatywne wobec małżeństwa, jak np. kohabitacja. Dana forma wydaje się wpisywać w model tzw. zindywidualizowanych relacji międzyludzkich i - jak zaznacza Anna Kwak - „tak rozumiany układ pozwala na elastyczność w formułowaniu zasad i zobowiązań" 55 , a oparty o uczucie (nie o zobowiązania formalne) trwa dopóki trwa samo uniesienie.

Innym dylematem, który może się okazać źródłem dyskomfortu, jest kwestia związana z zachowaniem „równowagi między autonomią a wspólnotą uczuć i doświadczeń [...], aby bliskość nie zmieniła się we wzajemne uzależnienie partnerów” "56. Niegdyś na ten aspekt zwracał uwagę Erich Fromm, pisząc, że „pragnienie zjednoczenia z drugim człowiekiem jest najpotężniejszym dążeniem ludzi. Jest ono najbardziej podstawową namiętnością, jest siłą cementującą cały rodzaj ludzki, klan, rodzinę, społeczeństwo" ${ }^{57}$. Dzisiaj jednak namiętność ta jest bardzo ryzykowna, ponieważ wiąże się z widmem tzw. zespolenia symbiotycznego, tj. stania się , „częścią składową drugiego człowieka" ${ }^{58}$ lub włączenia go w obręb mojego „Ja”.

Jest to $\mathrm{w}$ istocie kwestia uzależnienia jednego partnera od drugiego. Giddens określa ten problem mianem „współuzależnienia”, tj. tzw. odwrotnej refleksyjności ${ }^{59}$, kiedy osoba współuzależniona pragnie, by ktoś inny (poza nią) określał jej potrzeby. Jednostka współuzależniona porzuca radykalnie te zadania, dopasowując się całkowicie do swojego partnera. To właśnie jego pragnienia, oczekiwania i aspi-

53 D. Popenoe, Cohabitation, Marriage and Child Wellbeing: A Cross-national Perspective, "Social Science and Public Policy" 2009, No. 46 (5).

54 P.R. Amato, A. Booth, D. Johnson, S. J. Roberts, Alone Together. How Marriage in America is Changing, Cambridge - London 2007, s. 7.

55 A. Kwak, Współczesne związi heteroseksualne: matżeństwa (dobrowolnie bezdzietne), kohabitacje, LAT, Warszawa 2014, s. 226.

56 A. Giddens, Nowoczesność..., s. 134.

57 E. Fromm, O sztuce miłości, przeł. A. Bogdański, Poznań 2000, s. 37.

58 Ibidem, s. 38.

59 A. Giddens, Przemiany..., s. 110. 
racje są najważniejsze i finalnie przetransponowane są jako właściwe pragnienia, oczekiwania i aspiracje osoby współuzależnionej.

Nie jest to jedyna forma uzależnienia. Oprócz podporządkowania drugiej osobie, możliwa jest także sytuacja uzależnienia od samego związku. Giddens komentuje to w sposób następujący: ,[...] partnerzy żyjący w takich związkach nie konstruują swojego życia wokół gotowych uzależnień, lecz potrzebują związku dla zaspokojenia potrzeby bezpieczeństwa, której inaczej zaspokoić nie potrafią" ${ }^{00}$. Jest to problem nadmiernej potrzeby bliskości nie tyle względem drugiej osoby, co samej więzi. To właśnie ta więź daje uzależnionej jednostce poczucie bezpieczeństwa ontologicznego. Problem ten dostrzega również Zygmunt Bauman, którego zdaniem taka jednostka często „,wietrzy groźbę opresji, każde nieprzelotne zaangażowanie to dla niej groźba popadnięcia w obezwładniającą zależność" ${ }^{11}$. Filozof wskazuje też, że ,zaangażowanie w związek z drugą osobą [...], a zwłaszcza bezwarunkowe zaangażowanie, zaangażowanie »do grobowej deski« [...], przypomina pułapkę, której należy za wszelką cenę uniknąć. [...] Młodzi ludzie, chcąc wyrazić swoją aprobatę, mówią, że coś jest cool, a więc dosłownie: »chłodne«" 62 . Bauman zwraca tutaj uwagę na ważny aspekt poszanowania wzajemnej niezależności i autonomii. Są to wartości, które mogą być zagrożone przez popadnięcie w uzależnienie zarówno od drugiej osoby, jak i samego związku.

Możliwa jest także sytuacja, w której to partnerzy mogą się znajdować zbyt „daleko od siebie”. Podkreśla to para niemieckich socjologów, Beck i Beck-Gersheim, zwracając uwagę na problemem napięcia między „byciem razem” a „byciem sobą”. Pytają oni o to:

[...] jak wiele miejsca pozostaje w biografii opartej na zasadzie „zrób to sam” ze wszystkimi jej presjami i ograniczeniami na partnera/partnerkę, z jego/jej własnymi planami i problemami? W jaki sposób druga osoba może stać się dodatkowym lub szkodliwym czynnikiem? Do jakiego stopnia jest możliwe dzielenie z kimś życia, jeśli kontekst społeczny zachęca do koncentrowania się na własnym interesie? ${ }^{63}$

Postawione pytania dotyczą problemu aberracji, jaki niosą ze sobą wartości współczesnych, zindywidualizowanych społeczeństw, tj. dysonansu między potrzebą zawiązywania relacji międzyludzkich z jednej strony (życia intymnego, małżeńskiego, rodzinnego) a pragnieniem samorealizacji z drugiej (życia jednostkowego, samorealizacji, kariery).

60 Ibidem, s. 113.

61 Z. Bauman, Razem osobno, Kraków 2007, s. 140.

62 Ibidem, s. 203-204.

63 U. Beck, E. Beck-Gersheim, op. cit., s. 53. 
Pobrane z czasopisma Annales I - Philosophy and Sociology http://philosophia.annales.umcs.pl Data: 26/04/2023 13:02:52

Źródłem napięć jest zatem kwestia różnic między partnerami. Każdy z uczestników relacji ma „własne życie”, które chce kontynuować na etapie związku, natomiast rzeczywistość sama w sobie nie daje wskazówek, jak pogodzić dwa odrębne projekty życiowe. Gdy indywidualne projekty poruszają się po zupełnie innych traktach lub kolidują ze sobą, wielkie oczekiwania wiązane z relacją osobistą zamieniają się w równie wielkie rozczarowanie. Dodatkowo wspomniany już paradygmat elastyczności zdaniem Becka i Beck-Gersheim w sposób negatywny wpływa na kwestię rozwiązania tego problemu. Według badaczy niegdyś starano się ,przepracowywać” wszelkie dylematy, rezygnować z niektórych oczekiwań na rzecz trwania samego związku. Dzisiaj natomiast w przypadku niemożności osiągnięcia pełniejszej integracji, tj. wypracowania dla siebie nowego wspólnego projektu, „permanentna etyka zmian” podpowiada, by zrezygnować z takiej relacji ${ }^{64}$.

Współczesne przemiany intymności materializują się nie tylko w „treści” samego związku, jego różnorodnych formach ${ }^{65}$, ale mogą też prowadzić do intencjonalnego rezygnowania $\mathrm{z}$ takiego typu relacji. W kontekście procesów indywidualizujących społeczeństwo (gdy jednostka jest socjalizowana niejako do przybierania postaw skoncentrowanych na własnej osobie, chociażby na polu kariery zawodowej) coraz atrakcyjniejszym rozwiązaniem może być życie „solo". Bycie singlem jest celowym wyborem życia w pojedynkę. "Singielstwo” nie spotyka się obecnie z takim ,piętnem” społecznym, jak przed laty. Dawniej ktoś realizujący dany wzorzec postrzegany był jako „stara panna” lub „stary kawaler”. Dzisiaj singiel to „osoba świadomie realizująca samotny styl życia [...], która przestaje być traktowana jako ktoś, kto uległ poważnej dewiacji społecznej [...]. To ludzie, którzy [...] mogą więcej »korzystać z życia«, mogą łatwiej zaspokoić swoje potrzeby, mają większą możliwość samorealizacji”" ${ }^{66}$

W takiej sytuacji bliska relacja międzyludzka może być tożsama z utratą indywidualnej autonomii i niezależności. Małżeństwo i rodzina, będące w przeszłości gwarantem bezpieczeństwa (fizycznego, ekonomicznego, ontologicznego) i definiensem jednostki w społeczeństwie, obecnie mogą stanowić o przeszkodzie do pełniejszej samorealizacji i autoekspresji ${ }^{67}$. W tym sensie poczucie samotności i niepokoju, które może doskwierać osobom żyjącym w pojedynkę, jawi się jako mniej kłujące niż sam związek (postrzegany często jako pewna forma opresji).

64 Ibidem, s. 93.

65 Mam na myśli tutaj nie tylko przywołaną kohabitację, ale też coraz popularniejsze układy typu LAT (Living Apart Together), kiedy para pozostaje ze sobą w związku intymnym, ale każda ze stron mieszka we własnym mieszkaniu. Innym ciekawym przykładem jest tzw. intencjonalna bezdzietność, gdy para/małżeństwo celowo decyduje się nie posiadać i nie wychowywać dziecka.

66 M. Torczyńska-Jarecka, op. cit., s. 99.

67 J. Czarnecka, Wielkomiejscy single, Warszawa 2011, s. 55-56. 
Pobrane z czasopisma Annales I - Philosophy and Sociology http://philosophia.annales.umcs.pl Data: 26/04/2023 13:02:52

Warto podkreślić, iż bliskość nie jest kategorią zarezerwowaną jedynie dla związku małżeńskiego, partnerskiego czy erotycznego. Może ona być realizowana także na polu relacji przyjacielskich czy rodzinnych, skutecznie kompensując negatywne aspekty życia w pojedynkę.

\section{ZAKOŃCZENIE}

Wedle przytoczonych w niniejszym artykule tez dzisiejsze przemiany społeczno-kulturowe pchają nas w stronę powszechnej indywidualizacji. Proces ten, przenikając rzeczywistość makrospołeczną, odciska piętno zarówno na poziomie mikrospołecznym, jak i sferze jednostkowych postaw mentalnych. Dlatego aspekt bliskich relacji intymnych nie powinien być z tego procesu wyłączany.

Zaznaczony tutaj negatywny wpływ owych przemian prowadzi do problemu erozji w charakterze współczesnej intymności. Dzisiejszy rozdźwięk między kategorią „Ja” a kategorią „My” może być postrzegany jako źródło napięć, stresów i frustracji w kwestii formowania związków lub nawet jako argument do wyboru stylu życia w pojedynkę. Współczesny świat jest niewątpliwie problematycznym gruntem dla omawianej sfery. Od dzisiejszych relacji intymnych wymaga się spełnienia obietnicy bliskości, satysfakcji i bezpieczeństwa, oczekując jednocześnie, że druga osoba nie będzie naruszała naszej wolności. Dlatego, paradoksalnie, nie dziwi lęk przed samotnością czy utratą bliskiej relacji, z równoczesnym lękiem „przed innymi, lękiem przed zaangażowaniem się w zbyt głęboką relację" ${ }^{68}$.

Warto zauważyć za Jean-Luc Nancy, że to właśnie życie dzielone z drugą osobą od zawsze stanowi najbardziej naturalny stan egzystencji ludzkiej ${ }^{69}$. Nie inaczej jest i dzisiaj pomimo indywidualizacji rzeczywistości społecznej. Przemiany intymności i idące $\mathrm{z}$ nią $\mathrm{w}$ parze problemy nie powinny zacierać tego, że człowiek w relacjach ,z innym człowiekiem otrzymuje możliwość zaistnienia jako jednostka" ${ }^{70}$. Związek intymny jest bowiem odbiciem osobowości, elementem jednostkowej tożsamości (refleksyjnie tworzonej biografii), a zatem niczym innym, jak utwierdzeniem własnej indywidualności.

\section{BIBLIOGRAFIA}

Adamski F., Rodzina, wymiar społeczno-kulturowy, Kraków 2002.

Amato P.R., Booth A., Johnson D., Roberts S.J., Alone Together. How Marriage in America is Changing, Cambridge - London 2007.

68 M. Olcoń-Kubicka, op. cit., s. 34.

69 J.-L. Nancy, Inoperative Community, Minneapolis 1995.

70 M. Olcoń-Kubicka, op. cit., s. 195. 
Bauman Z., Liquid Modernity, Cambridge 2000.

Bauman Z., Ponowoczesność jako źródło cierpień, Warszawa 2000.

Bauman Z., Razem osobno, Kraków 2007.

Beck U., Społeczeństwo ryzyka. W drodze do innej nowoczesności, przeł. S. Cieśla, Warszawa 2002.

Beck U., Beck-Gersheim E., The Normal Chaos of Love, Cambridge 1995.

Berger P., Rewolucja kapitalistyczna. Pięćdziesiąt tez o dobrobycie, równości i wolności, przeł. Z. Simbierowicz, Warszawa 1995.

Bokszański Z., Indywidualizm a zmiana społeczna, Warszawa 2007.

Burkhart G., Familiensoziologie, Konstanz 2008.

Craft K., Równości i nierówności w II Rzeczypospolitej. Prawo malżeńskie w dyskursie publicznym na przełomie lat dwudziestych i trzydziestych, [w:] Kobieta i matzeństwo. Społeczno-kulturowe aspekty seksualności. Wiek XIX i XX, red. A. Żarnowska, A. Szwarc, Warszawa 2004.

Czarnecka J., Wielkomiejscy single, Warszawa 2011.

Dewey J., Individualism Old and New, Amherst - New York 1999.

Elias N., Die Gesellschaft der Individuen, Frankfurt 1987.

Fromm E., O sztuce miłości, przeł. A. Bogdański, Poznań 2000.

Giddens A., Nowoczesność i tożsamość, przeł. A. Szulżycka, Warszawa 2012.

Giddens A., Przemiany intymności, przeł. A. Szulżycka, Warszawa 2015.

Giddens A., Socjologia, przeł. P. Tomanek, A. Szulżycka, O. Siara, Warszawa 2012.

Giddens A., The Consequences of Modernity, Cambridge 1994.

Grochalska M., Kobiety w związkach jako ofiary dyskursu ,szczęśliwej rodziny”, [w:] Zagadnienia matżeństwa i rodziny w perspektywie feministyczno-genderowej, red. K. Slany, Kraków 2013.

Homeles M., The Preciarnousness of Choice in the New Sentimental Order: A Response to Bawin-Legros, "Current Sociology" 2004, Vol. 52.

Jacyno M., Kultura indywidualizmu, Warszawa 2007.

Jamieson L., Intimacy Transformed? A Critical look at "Pure Relationship", "Sociology" 1999, Vol. 33, DOI: https://doi.org/10.1017/S0038038599000310.

Kmita J., O kulturze symbolicznej, Warszawa 1982.

Kocik L., Wzory matżeństwa i rodziny od tradycyjnej jednorodności do wspótczesnych skrajności, Kraków 2002.

Kopaliński W., Intymność, [w:] Stownik wyrazów obcych i zwrotów obcojęzycznych, Warszawa 1998. Kwak A., Wspótczesne związki heteroseksualne: matżeństwa (dobrowolnie bezdzietne), kohabitacje, LAT, Warszawa 2014.

Marody M., Między neutralnościa a zaangażowaniem. O socjologii Norberta Eliasa, [w:] Społeczeństwo jednostek, red. N. Elias, Warszawa 2008.

Nancy J.-L., Inoperative Community, Minneapolis 1995.

Olcoń-Kubicka M., Indywidualizacja a nowe formy wspólnotowości, Warszawa 2009.

Popenoe D., Cohabitation, Marriage and Child Wellbeing: A Cross-national Perspective, "Social Science and Public Policy" 2009, No. 46 (5).

Renzetti C.M., Curran D.J., Kobiety, mężczyźni i społeczeństwo, przeł. A. Gromkowska-Melosik, Warszawa 2005.

Ronek G., Koncepcja demokratycznej rodziny Anthony'ego Giddensa, [w:] Miłość, wierność, uczciwość na rozstajach wspótczesności. Kształty rodziny współczesnej, red. W. Muszyński, E. Sikorska, Torun 2008.

Schmidt F., Para, mieszkanie, matżeństwo. Dynamika związków matżeńskich intymnych na tle przemian historycznych $i$ wspótczesnych dyskusji o procesach indywidualizacji, Warszawa - Toruń 2015. 
Schmidt F., Teorie kuchenne. Dialektyka przyzwyczajeń i refleksyjności w koncepcji Jeana Claude'a Kaufmanna, „Kultura i Społeczeństwo” 2010, nr 1.

Sekuła E.A., Giddens o miłości i nie tylko. Recenzja ksiązki „Przemiany intymności” A. Giddensa, „Kultura Popularna” 2006, nr 4.

Sennett R., The Fall of Public Man. On the Social Psychology of Capitalism, New York 1996.

Simmel G., Socjologia, przeł. M. Łukasiewicz, Warszawa 2005.

Slany K., Alternatywne formy życia matżeńsko-rodzinnego w ponowoczesnym świecie, Kraków 2002. Styk J., Ewolucja chłopskiego systemu wartości, Lublin 1988.

Szacki J., Indywidualizm i kolektywizm, [w:] Encyklopedia socjologii. Suplement, Warszawa 2005. Sztompka P., Socjologia. Analiza społeczeństwa, Kraków 2012.

Torczyńska-Jarecka M., Samotność z wyboru jako alternatywny styl życia, [w:] Kulturowe wyzwania XXI wieku. Szkice z socjologii, antropologii i psychologii społecznej, red. U. Kusio, Lublin 2005.

Tymicki K., Starokawalerstwo i staropanieństwo. Analiza zjawiska, „Studia Socjologiczne” 2001, nr 163.

Tyszka Z., Rodzina współczesna - jej geneza i kierunki przemian, [w:] Współczesne rodziny polskie - ich stan i kierunek przemian, red. Z. Tyszka, Poznań 2001.

Żarnowski J., Rodzina w czasach cywilizacyjnego przyśpieszenia: Europa i Polska 1918-1989, [w:] Rodzina, prywatność, intymność, red. D. Kawała, A. Walaszek, A. Żarnowska, Warszawa 2005.

\section{SUMMARY}

Friendship, love, a close relationship with another person - at the certain stage of life these concepts affect almost every one of us. It is worth to highlight, that our relationships with other people can provide a valuable piece of information not only about ourselves, but also about the state or condition of our society. Social reality is a field where a variety of processes and transformations takes place and along with them follows the change of the nature of close interpersonal relationships. Western societies are udeniably headed towards generalized individualization, where individuals are freed from the rigid social structures and claim the right to greater autonomy, independence and self-reliance in creating their own identity. How do the above transformations contribute to the aspect of intimate relationships? Does intimacy finds itself in "a state of siege" and the relationship with another person appears as a source of stress and tension? Are contemporary transformations of intimacy cause an opportunity or rather a chance to create more expressive and fulfilling relationships than in the past?

Keywords: intimacy; relationship; marriage; individualization phenomenon; tension

\section{STRESZCZENIE}

Przyjaźń, miłość, bliski związek z drugą osobą to pojęcia, które na pewnym etapie życia dotyczą niemal każdego z nas. Warto zaznaczyć, iż to, jak wyglądają nasze relacje z innymi ludźmi, może dostarczyć cennych informacji nie tylko o nas samych, ale też może wiele powiedzieć o kondycji naszego społeczeństwa. Rzeczywistość społeczna jest polem, na którym zachodzą liczne procesy i przemiany, a wraz z nimi zmienia się charakter bliskich więzi międzyludzkich. Społeczeństwa zachodnie niewątpliwie zmierzają w stronę zgeneralizowanej indywidualizacji, gdzie jednostka wyzwala się spod skostniałych struktur społecznych i rości sobie prawo do coraz większej autonomii, niezależności i samodzielności w tworzeniu własnej tożsamości. Jak zatem 
Pobrane z czasopisma Annales I - Philosophy and Sociology http://philosophia.annales.umcs.pl Data: 26/04/2023 13:02:52

przytoczone powyżej przekształcenia przekładają się na aspekt relacji intymnych? Czy obecnie intymność faktyczne znalazła się w ,stanie oblężenia”, a związek z drugą osobą jawi się jako źródło napięć i stresów? Czy współczesne przemiany intymności stwarzają raczej szansę na zawieranie bardziej wyrazistych i pełniejszych więzi niż kiedykolwiek w przeszłości?

Słowa kluczowe: intymność; związek; małżeństwo; zjawisko indywidualizacji; napięcie 
Pobrane z czasopisma Annales I - Philosophy and Sociology http://philosophia.annales.umcs.pl Data: 26/04/2023 13:02:52 